\title{
TOKSISITAS BIOINSEKTISIDA EKSTRAK KULIT JERUK TERHADAP KUTU LONCAT JERUK Diaphorina citri Kuwayama (Hemiptera: Psyllidae) SEBAGAI VEKTOR PENYAKIT CVPD
}

\author{
Bioinsecticide Toxicity of Citrus Peel Extract Against Citrus Psyllid Diaphorina citri \\ Kuwayama (Hemiptera: Psyllidae) as CVPD Disease Vector
}

\author{
Susi Wuryantini, Harwanto, dan Rizky Arya Yudistira \\ Balai Penelitian Tanaman jeruk dan Buah Subtropika \\ Jl. Raya Tlekung No. 1 Junrejo, Batu, Jawa Timur 65301 \\ Korespondensi: Susi.Email: susi_wur@yahoo.com
}

\begin{abstract}
ABSTRAK
Kutu loncat jeruk Diaphorina citri adalah hama penting pada tanaman jeruk karena perannya sebagai vektor penyakit Citrus Vein Phloem Degeneration (CVPD). Penelitian merupakan pengujian lanjutan dari uji pendahuluan yang dilakukan sebelumnya. Tujuan penelitian adalah untuk mengetahui konsentrasi yang efektif dari bioinsektisida ekstrak kulit jeruk Japansche Citroen (JC) untuk mengendalikan $D$. citri fase nimfa dan imago. Konsentrasi yang diuji adalah $0 \%$ (kontrol); $0.01 \% ; 0.1 \% ; 1 \%$; dan $10 \%$ (v/v) dengan pembanding insektisida imidakloprid $0.1 \%$. Hasil pengujian menunjukkan bahwa ekstrak kulit jeruk JC pada konsentrasi 0.1 efektif mengendalikan nimfa $D$. citri mulai 96 jam setelah aplikasi (JSA) dengan mortalitas $69 \%$. Konsentrasi $1 \%$ efektif mulai 24 JSA dengan mortalitas $65 \%$ dan setelahnya mengalami peningkatan hingga mencapai $100 \%$ pada 120 JSA, tidak berbeda nyata dengan perlakuan konsentrasi $10 \%$ dan insektisida imidakloprid $0.1 \%$ dan berbeda nyata dengan perlakuan yang lain serta kontrol. Pada perlakuan terhadap imago konsentrasi yang mampu memberikan mortalitas imago di atas 50\% adalah konsentrasi tertinggi $10 \%$ pada 96 , 120 dan 144 JSA. Hasil penghitungan nilai probit pada 24 JSA nilai LC S0 $_{50}$ ada nimfa adalah 1.86 dan $\mathrm{LC}_{90}$ adalah 9.10. Perlakuan pada imago $\mathrm{LC}_{50}$ pada 48 JSA adalah 21.34 dan LC 90 tidak tercapai. Hasil perhitungan nilai $\mathrm{LC}_{50}$ dan $\mathrm{LC}_{90}$ menunjukkan nilai pada nimfa lebih kecil dibandingkan pada imago. Hal ini menunjukkan bahwa bioinsektisida ekstrak kulit jeruk JC lebih efektif terhadap nimfa daripada imago kutu loncat $D$. citri. Bioinsektisida ekstrak kulit jeruk JC efektif terhadap kutu loncat $D$. citri fase nimfa pada konsentrasi 0,1 dan $1 \%$ dan terhadap fase imago efektif pada konsentrasi $10 \%$.
\end{abstract}

Kata kunci: Toksisitas, ekstrak kulit jeruk, Diaphorina citri

\begin{abstract}
Diaphorina citri is an important pest in citrus plants because of its role as a vector of Citrus Vein Phloem Degeneration (CVPD) disease. The study was a follow-up test of the preliminary tests carried out previously. The aim of this study was to determine the effective concentration of bioinsecticide of Japansche Citroen (JC) orange peel extract in controlling D. citri in the phases of nymph and imago. The concentration tested was 0\% (control); 0.01\%; 0.1\%; 1\%; and $10 \%(\mathrm{v} / \mathrm{v})$ with a comparison of imidacloprid insecticide $0.1 \%$. The test results showed that the JC citrus peel extract at a concentration of 0.1 effectively controlled the D. citri nymph starting at 96 hours after application (HAA) with a mortality of $69 \%$. The concentration of $1 \%$ was effective from 24 HAA with a mortality of $65 \%$ and thereafter reaching up to $100 \%$ at 120 HAA, this was not significantly different from the $10 \%$ concentration treatment and imidacloprid insecticide $0.1 \%$, yet was significantly different from other treatments and controls. Citrus peel extract was effective for controlling imago of D. citri on 10\%
\end{abstract}


concentration. The concentration that was able to provide mortality above $50 \%$ was the highest concentration of $10 \%$ at 96,120 and 144 HAA. The results of the probit analysis showed that the $L C_{50}$ values at 24 HAA on nymphs was 1.86 and the $L C_{90}$ value was 9.10. The treatment on imago the $L C_{50}$ at 48 HAA was 21.34 and the LC 90 was not achieved. The results of the calculation of the $L C_{50}$ and $L C_{90}$ values showed that the value in nymphs was smaller than in imago. This showed that the bioinsecticide of JC citrus peel extract was more effective against nymphs than imago of D. citri. Bioinsecticide of JC citrus peel extract was effective against psyllid nymph of D. citri at concentrations of 0.1 and $1 \%$ and against the imago phase was effective at $10 \%$.

Keywords: Toxicity, citrus peel extract, Diaphorina citri

\section{PENDAHULUAN}

Usaha agribisnis jeruk tidak lepas dari permasalahan yang dapat menyebabkan penurunan kuantitas dan kualitas produksi. Penyakit Citrus Vein Phloem Degenaration (CVPD) atau yang dikenal juga dengan Huanglongbing (HLB) sampai saat ini menjadi penyakit utama jeruk di Indonesia dan beberapa negara di dunia. Kerugian yang ditimbulkan akibat serangan penyakit ini adalah kematian tanaman, sehingga produksi jeruk menurun. Sebagai gambaran menurut Dwiastuti (2000), serangan penyakit CVPD di Bali Utara menyebabkan penurunan produksi jeruk sampai 60\%. Pada tahun 2012 serangan CVPD di wilayah Kabupaten Bangli, Bali mencapai 54,38\% dengan intensitas 9.86\% (Swari et al. 2014). Penyebaran CVPD di Bali disebabkan karena bibit yang tidak berlabel bebas penyakit mencapai $83 \%$ (Wirawan et al. 2003). Pertambahan luas serangan CVPD di Bali pada periode April sampai September 2009 berkisar antara 20 sampai 29\% (Wijaya et al. 2010). Luas panen nasional tahun 2011 adalah 47,181 ribu ha menurun pada tahun berikutnya menjadi 46,187 ribu ha dan berangsur angsur kembali naik menjadi 48,119 ribu ha di tahun 2015. Secara umum dalam kurun waktu tersebut mengalami penurunan sebesar 5,83\% (BPS dan Dirjen Hortikultura 2015).

Gejala penyakit CVPD di antaranya adalah daun yang menguning atau klorosis, atau belang-belang tidak teratur yang disebut pula sebagai blotching, yellow shoot dan greening sektoral pada tanaman yang tidak normal pertumbuhannya. Gejala tersebut berpola tidak teratur dan bervariasi, ukuran daun mengecil dan kaku, pertumbuhannya cenderung mengarah ke atas (Wijaya 2003; Dwiastuti et al. 2003; Dwiastuti et al. 2011; Swari et al. 2014). Pada tanaman yang terserang CVPD buah bentuknya tidak sempurna, dan rasa menjadi lebih asam (Bove 2006). Penyakit CVPD penyebarannya relatif cepat karena adanya serangga vektor yaitu hama kutu loncat jeruk Diaphorina citri. Hama ini dikategorikan hama utama karena selain sebagai hama kutu loncat tersebut juga berperan terhadap kerugian tidak langsung yang diakibatkan karena perannya sebagai vektor CVPD (Dwiastuti et al. 2011; Balitjestro 2015).

Nimfa dan imago D. citri mengisap cairan daun terutama bagian tunas. Serangan mengakibatkan daun jeruk menjadi mengkerut, keriting, layu dan serangan parah dapat mengakibatkan tunas kering dan rontok. Kerusakan yang berat dapat menyebabkan kematian tanaman. Nimfa mengeluarkan sekresi berwarna putih berlilin seperti benang berbentuk spiral dan embun madu. Sekresi dan embun madu tersebut yang jatuh pada permukaan daun dapat menjadi media tumbuhnya cendawan jelaga yang melapisi daun sehingga menyebabkan proses fotosintesis terganggu (Dwiastuti et al. 2011; Mead \& Fasulo 2011).

Pengendalian penyakit CVPD harus dilakukan secara terintegrasi utamanya dengan penggunaan bibit bebas penyakit 
dan pengendalian serangga vektornya yaitu kutu loncat jeruk D. citri. Pengendalian terhadap hama tersebut selama ini banyak dilakukan dengan insektisida kimia. Untuk mengurangi dampak negatif yang ditimbulkan akibat penggunaan insektisida kimia telah banyak dikembangkan insektisida yang lebih ramah lingkungan, yaitu dari bahan nabati yang terdapat dalam tanaman. Kandungan metabolit sekunder tanaman tertentu dapat berfungsi sebagai pengendali serangga baik sebagai pembunuh, penarik (atraktan) maupun sebagai penolak atau repellent (Harwanto et al. 2015). Di antara sifat-sifat insektisida nabati adalah mudah terurai di alam, musuh alami relatif aman, dapat dipadukan dengan komponen pengendali yang lain, laju resistensi dapat lebih lambat, ketahanan dan keberlanjutan berusahatani dapat dijamin (Dadang dan Prijono 2011).

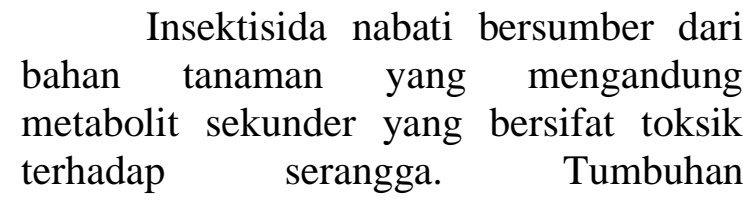
memproduksi berbagai jenis metabolit sekunder di antaranya flavonoid, terpenoid, dan alkaloid, yang berfungsi sebagai pertahanan diri. Biasanya metabolit sekunder disimpan dalam jaringan tertentu dan dipisahkan dari sitoplasma atau disimpan dalam bentuk senyawa tidak aktif (Bernays dan Chapman 1994). Kulit jeruk adalah limbah organik yang dapat dimanfaatkan sebagai bahan insektisida. Kulit jeruk mengandung metabolit sekunder yaitu beberapa senyawa yang sebagian besar tergolong dalam kelompok monoterpenoid, asam lemak dan seskuiterpenoid. Senyawa-senyawa tersebut di antaranya berfungsi sebagai insektisida (Katoh et al. 2005; Harwanto 2015). Pada kegiatan ini kulit jeruk yang digunakan adalah kulit jeruk JC yang merupakan limbah buangan dari kegiatan proses pemisahan biji jeruk JC yang digunakan sebagai materi batang bawah jeruk. Harwanto et al. (2015) melaporkan, bahwa ekstrak kulit jeruk JC toksik terhadap kutu daun Aphis gossypii dan kutu loncat D. citri pada konsentrasi uji $10 \%$ dengan berbagai pelarut, dan pelarut aseton memberikan efektivitas yang lebih tinggi dibandingkan dengan pelarut lain yaitu akuades, diklormetan, heksan, dan metanol. Hal ini membuat ekstrak dengan pelarut aseton dipilih untuk dilanjutkan pada pengujian ini, dengan mencari konsentrasi efektif.

Pengembangan penggunaan bahan pengendali yang ramah lingkungan salah satunya didasari oleh meningkatnya pengetahuan dan kesejahteraan lapisan masyarakat tertentu di Indonesia. Hal tersebut memberikan peluang penggunaan pestisida nabati masih cukup terbuka, yaitu dengan penyediaan produk pertanian organik. Namun di sisi lain terdapat pula beberapa kendala di antaranya efek yang lambat, membanjirnya insektisida kimia sintetik dengan harga yang relatif murah, keterbatasan dan keseragaman bahan baku, perijinan yang sulit, dan kurangnya kesadaran petani (Yusuf 2012). Oleh karena itu masih terus diperlukan penggalian potensi lebih lanjut untuk peningkatan efisiensi penggunaan insektisida nabati. Tujuan dari penelitian ini adalah untuk mengetahui konsentrasi uji dari bioinsektisida nabati ekstrak kulit jeruk JC yang efektif untuk pengendalian hama kutu loncat jeruk fase nimfa dan imago.

\section{BAHAN DAN METODE}

Penelitian dilakukan di laboratorium entomologi dan rumah kasa Balai Penelitian Tanaman Jeruk dan Buah Subtropika (Balitjestro) pada bulan Januari sampai April 2017. Kutu loncat jeruk D. citri yang digunakan adalah koleksi yang ada di Balitjestro yang diperbanyak sesuai dengan kebutuhan penelitian. Kulit jeruk JC yang digunakan diperoleh dari limbah ekstraksi biji yang akan digunakan sebagai materi batang bawah pembuatan bibit jeruk.

\section{Metode Penelitian}

\section{Pembuatan Ekstrak Bioinsektisida}

Metode yang digunakan dalam pembuatan ekstrak bioinsektisida ialah 
maserasi. Maserasi merupakan cara ekstraksi yang paling sederhana. Bahan yang digunakan dihaluskan berupa serbuk kasar, dilarutkan dengan bahan pengekstraksi. (Harborne 1993; Voight R 1995). Kulit jeruk JC yang digunakan dalam penelitian diperoleh dari limbah hasil esktraksi biji jeruk sebagai bahan benih batang bawah jeruk. Kulit buah jeruk yang digunakan diiris tipis dan dikeringkan pada suhu $40^{\circ} \mathrm{C}$ kemudian dibuat menjadi tepung dengan blender. Tepung kulit jeruk JC direndam dalam aseton dengan perbandingan 1:2 (v/v) pada suhu ruang selama 24 jam. Penggunaan pelarut aseton dalam penelitian ini berdasarkan dari penelitian sebelumnya (Harwanto et al. 2005). Hasil perendaman selanjutnya disaring untuk mendapatkan filtratnya. Proses selanjutnya adalah penguapan, filtrat yang dihasilkan diuapkan dengan rotary evaporator hingga terbentuk cairan pekat yang umum disebut ekstrak. Ekstrak tersebut merupakan bahan yang digunakan dalam penelitian ini.

\section{Penyediaan Serangga Uji Diaphorina citri}

Serangga uji yang digunakan yaitu D. citri fase nimfa, instar dua sampai tiga dan imago. Perbanyakan D. citri dipersiapkan dengan memilih induk yang ada dari koleksi yang ada di rumah kasa laboratorium Entomologi Balitjestro. Perbanyakan dilakukan di rumah kasa. Tanaman inang yang digunakan untuk perbanyakan adalah kemuning (Murraya paniculata). Induk $D$ citri diinfestasikan pada tunas kemuning yang sudah disiapkan sebagai tempat peletakan telur. Telur yang dihasilkan dipisahkan dari induknya dan dipelihara sampai fase nimfa dan imago dan jumlahnya memenuhi untuk perlakuan. Dalam melakukan perbanyakan serangga uji, karena target pengujian adalah fase $D$. citri yang berbeda, hal penting yang perlu diperhatikan adalah pengelolaan waktu perbanyakan agar diperoleh fase yang diperlukan dalam waktu yang bersamaan.

\section{Aplikasi Bioinsektisida Ektrak Kulit Jeruk JC}

Bioinsektisida yang diuji yaitu ekstrak kulit jeruk JC yang diencerkan sesuai dengan konsentrasi perlakuan. Pengenceran ekstrak menggunakan akuades. Penelitian ini menggunakan Rancangan Acak Lengkap (RAL) dengan enam perlakuan yaitu ekstrak kulit jeruk JC dengan konsentrasi $0,01 \% ; 0,1 \% ; 1 \% ; 10 \%$; perlakuan insektisida pembanding imidakloprid $0,1 \%$ dan kontrol. Masingmasing perlakuan terdiri atas lima ulangan. Percobaan terdiri dari dua unit yaitu pengujian terhadap fase nimfa dan fase imago. Serangga uji masing-masing fase nimfa dan imago disiapkan dengan menginfestasikan pada tunas tanaman jeruk sebanyak 20 ekor per tunas. Aplikasi bioinsektisida terhadap serangga uji dilakukan dengan menyemprotkan secara langsung larutan ekstrak kulit jeruk JC sesuai dengan konsentrasi perlakuan. Pengamatan dilakukan pad 2, 4, 24, 48, 72, 96, 120 dan 144 jam setelah aplikasi. Parameter yang diamati adalah jumlah serangga uji yang mati pada tiap perlakuan dan ulangan.

\section{Analisis Data}

Data jumlah serangga yang mati pada tiap perlakuan dihitung persentase kematiannya (mortalitas). Data mortalitas tersebut yang akan dianalisis menggunakan Rancangan Acak Lengkap (RAL) untuk mengetahui efektifitas masing-masing perlakuan. Lebih lanjut digunakan analisis Probit untuk mengetahui lethal dose $\left(\mathrm{LC}_{50}\right.$ dan $\mathrm{LC}_{90}$ ) dianalisis menggunakan program Excel.

\section{HASIL DAN PEMBAHASAN}

Berdasarkan hasil yang diperoleh dalam pengujian toksisitas ekstrak kulit jeruk JC untuk mengendalikan imago kutu loncat $D$. citri yang terlihat memberikan hasil yang efektif adalah konsentrasi yang paling tinggi yaitu $10 \%$. Hal tersebut ditunjukkan pada hasil pada 96 JSA dengan mortalitas sebensar 54\% (Tabel 1). 
Tabel 1. Mortalitas imago D. citri yang diaplikasi insektisida botani ekstrak kulit jeruk JC

\begin{tabular}{|c|c|c|c|c|c|c|c|c|}
\hline \multirow{3}{*}{ Perlakuan } & \multicolumn{8}{|c|}{ Persentase Mortalitas Imago D. citri (\%) } \\
\hline & & & 24 & 48 & 72 & 96 & & 144 \\
\hline & 2 JSA & 4 JSA & JSA & JSA & JSA & JSA & $120 \mathrm{JSA}$ & JSA \\
\hline Kontrol & $0^{\mathrm{b}}$ & $0^{\mathrm{b}}$ & $0^{\mathrm{c}}$ & $0^{\mathrm{c}}$ & $0^{\mathrm{d}}$ & $0^{\mathrm{d}}$ & $1^{\mathrm{d}}$ & $1^{\mathrm{d}}$ \\
\hline $0.01 \%$ & $0^{\mathrm{b}}$ & $0^{\mathrm{b}}$ & $0^{c}$ & $0^{c}$ & $0^{\mathrm{d}}$ & $0^{\mathrm{d}}$ & $1^{\mathrm{d}}$ & $1^{\mathrm{d}}$ \\
\hline $0.1 \%$ & $0^{\mathrm{b}}$ & $0^{\mathrm{b}}$ & $0^{\mathrm{c}}$ & $0^{c}$ & $3^{\mathrm{cd}}$ & $3^{\mathrm{d}}$ & $5^{\mathrm{d}}$ & $6^{\mathrm{d}}$ \\
\hline $1 \%$ & $0^{\mathrm{b}}$ & $0^{\mathrm{b}}$ & $3^{c}$ & $6^{c}$ & $10^{c}$ & $12^{\mathrm{c}}$ & $14^{\mathrm{c}}$ & $16^{\mathrm{c}}$ \\
\hline $10 \%$ & $0^{\mathrm{b}}$ & $1^{\mathrm{b}}$ & $9^{b}$ & $27^{\mathrm{b}}$ & $44^{\mathrm{b}}$ & $54^{\mathrm{b}}$ & $57^{\mathrm{b}}$ & $71^{\mathrm{b}}$ \\
\hline dakloprid $0,1 \%$ & $8^{\mathrm{a}}$ & $22^{\mathrm{a}}$ & $69^{a}$ & $95^{\mathrm{a}}$ & $100^{\mathrm{a}}$ & $100^{\mathrm{a}}$ & $100^{\mathrm{a}}$ & $100^{\mathrm{a}}$ \\
\hline
\end{tabular}

Keterangan: Angka yang didampingi huruf yang sama pada kolom yang sama menunjukkan tidak ada perbedaan yang nyata pada uji selang berganda Duncan (DMRT) pada taraf nyata 5\%.

Mortalitas selanjutnya meningkat pada 120 dan 144 JSA sebesar masingmasing $57 \%$ dan $71 \%$. Konsentrasi lebih rendah dari $10 \%$ terlihat kurang efektif terhadap pengendalian imago, yang ditunjukkan oleh mortalitas pada konsentrasi $1 \%$ pada pengamatan terakhir 144 JSA mortalitas yang dihasilkan hanya $16 \%$. Pada penelitian ini mortalitas imago D. citri pada 96 jam dengan konsentrasi tertinggi $10 \%$ adalah $54 \%$ berbeda nyata dengan perlakukan lain dengan mortalitas yang lebih rendah dan berbeda nyata dengan insektisida imidakloprid dengan mortalitas $100 \%$. Pada uji pendahuluan yang dilakukan pada konsentrasi yang sama mortalitasnya 58\% (Harwanto et al. 2016), sehingga dapat dinyatakan bahwa efektifitasnya terhadap imago relatif rendah.

Tabel 2. Mortalitas nimfa D. citri yang diaplikasi insektisida botani ekstrak kulit jeruk JC

\begin{tabular}{cllllllll}
\hline \multirow{2}{*}{ Perlakuan } & \multicolumn{8}{c}{ Persentase Mortalitas Nimfa D. citri (JSA) } \\
\cline { 2 - 9 } & 2 & 4 & 24 & 48 & 72 & 96 & 120 & 144 \\
\hline Kontrol & $0^{\mathrm{c}}$ & $0^{\mathrm{c}}$ & $0^{\mathrm{b}}$ & $0^{\mathrm{d}}$ & $0^{\mathrm{d}}$ & $0^{\mathrm{c}}$ & $0^{\mathrm{c}}$ & $3^{\mathrm{d}}$ \\
$0.01 \%$ & $0^{\mathrm{c}}$ & $0^{\mathrm{c}}$ & $0^{\mathrm{b}}$ & $1^{\mathrm{d}}$ & $2^{\mathrm{d}}$ & $0^{\mathrm{c}}$ & $7^{\mathrm{c}}$ & $9^{\mathrm{c}}$ \\
$0.1 \%$ & $0^{\mathrm{c}}$ & $5^{\mathrm{c}}$ & $5^{\mathrm{b}}$ & $13^{\mathrm{c}}$ & $47^{\mathrm{c}}$ & $69^{\mathrm{c}}$ & $73^{\mathrm{b}}$ & $77^{\mathrm{b}}$ \\
$1 \%$ & $0^{\mathrm{c}}$ & $5^{\mathrm{c}}$ & $65^{\mathrm{a}}$ & $72^{\mathrm{b}}$ & $88^{\mathrm{b}}$ & $99^{\mathrm{b}}$ & $100^{\mathrm{a}}$ & $100^{\mathrm{a}}$ \\
$10 \%$ & $11^{\mathrm{a}}$ & $12^{\mathrm{b}}$ & $70^{\mathrm{a}}$ & $96^{\mathrm{a}}$ & $97^{\mathrm{a}}$ & $100^{\mathrm{a}}$ & $100^{\mathrm{a}}$ & $100^{\mathrm{a}}$ \\
Imidakloprid $0,1 \%$ & $8^{\mathrm{b}}$ & $22^{\mathrm{a}}$ & $69^{\mathrm{a}}$ & $95^{\mathrm{a}}$ & $100^{\mathrm{a}}$ & $100^{\mathrm{a}}$ & $100^{\mathrm{a}}$ & $100^{\mathrm{a}}$ \\
\hline
\end{tabular}

Keterangan: Angka yang didampingi huruf yang sama pada kolom yang sama menunjukkan tidak ada perbedaan yang nyata pada uji selang berganda Duncan (DMRT) pada taraf nyata 5\%.

Ekstrak kulit jeruk JC yang diuji terhadap nimfa $D$. citri terlihat cukup efektif. Hal tersebut ditunjukkan oleh perlakuan konsentrasi $0,1 \%$ dapat mengendalikan nimfa $D$. citri dengan mortalitas mencapai $69 \%, 73 \%$ dan $77 \%$ masing-masing pada 96, 120 dan 144 JSA. Pada konsentrasi yang lebih tinggi yaitu $1 \%$ dan $10 \%$ mortalitas pada 24 JSA sudah diatas $50 \%$ yaitu $65 \%$ dan $70 \%$. Pada pengamatan berikutnya yaitu 48, 72, dan 96 JSA mortalitas nimfa $D$. citri pada perlakuan konsentrasi ekstrak kulit jeruk JC $1 \%$ berturut-turut adalah adalah $72 \%, 88 \%$, dan $99 \%$. Pada 120 JSA mortalitas nimfa $D$. citri sudah mencapai $100 \%$. Pada konsentrasi yang lebih tinggi yaitu $10 \%$ mortalitas nimfa D. citri $100 \%$ dicapai pada 96 JSA. 
Tabel 3. Nilai LC 50 dan LC90 ekstrak kulit jeruk yang diaplikasikan pada kutu loncat jeruk $D$. citri

\begin{tabular}{ccc}
\hline $\begin{array}{c}\text { Fase D. citri/ } \\
\text { Waktu pengamatan }\end{array}$ & $\begin{array}{c}\mathrm{LC}_{50} \\
(\%)\end{array}$ & $\begin{array}{c}\mathrm{LC}_{90} \\
(\%)\end{array}$ \\
\hline Nimfa : & & \\
24 JSA & 1.86 & 9.10 \\
48 JSA & 0.50 & 5.52 \\
72 JSA & 0.03 & 2.00 \\
\hline Imago : & - & - \\
24 JSA & 21.34 & - \\
48 JSA & 7.44 & 52.02 \\
72 JSA & 5.69 & 36.14 \\
\hline
\end{tabular}

Berdasarkan hasil analisis probit yang dilakukan diperoleh bahwa nilai $\mathrm{LC}_{50}$ untuk perlakuan terhadap nimfa pada 24 JSA adalah 1.86 dan nilai $\mathrm{LC}_{90}$ adalah 9.10. Nilai LC semakin menurun pada pengamatan selanjutnya. Perlakuan terhadap imago pada 24 JSA $\mathrm{LC}_{50}$ dan $\mathrm{LC}_{90}$ belum tercapai. Pada 48 JSA nilai $\mathrm{LC}_{50}$ adalah 21.34, pada 48 dan 72 JSA masing-masing adalah 7.44 dan 5.69. LC 90 pada 24 dan 48 JSA tidak tercapai. Pada 72 JSA sebesar 52.02 dan pada 96 JSA nilai LC $_{90}$ pada imago adalah 36.14. Aplikasi bioinsektisida ekstrak kulit jeruk JC pada nimfa D. citri terlihat lebih efektif dibandingkan dengan aplikasi pada imago, Hal tersebut terlihat pada hasil $\mathrm{LC}_{50}$ dan $\mathrm{LC}_{90}$ yang dicapai. Nilai LC yang lebih rendah pada perlakuan nimfa $D$. citri menunjukkan bahwa bioinsektisida ekstrak kulit jeruk JC lebih toksik dan efektif terhadap fase nimfa dibandingkan fase imago. Hasil penelitian Boina et al. (2009) bahwa Imago $D$. citri dengan paparan Imidakloprid toksisitas $\mathrm{LC}_{50}$ pada konsentrasi $0,09,0,31$ dan 0,08 masingmasing pada suhu $17^{\circ} \mathrm{C}, 27^{\circ} \mathrm{C}$ dan $37^{\circ} \mathrm{C}$. Insektisida golongan organofosfat, karbamat, avermektin dan neonicotinoid (imidakloprid) lebih efektif diterapkan pada kondisi suhu yang relatif panas diatas $25^{\circ} \mathrm{C}$ dibandingkan dengan piretroid yang sesuai diaplikasikan pada suhu rendah. Hal demikian dapat dijadikan pertimbangan untuk rotasi penggunaan insektisida untuk pengendalian $D$. citri.
Dari hasil analisis yang dilakukan baik dengan RAL maupun analisis probit terlihat bahwa insektisida botani ekstrak kulit jeruk JC yang diuji efektif terhadap nimfa, namun kurang efektif terhadap imago D. citri. Dengan demikian dapat dinyatakan bahwa bioinsektisida kulit jeruk JC dapat digunakan untuk pengendalian kutu loncat $D$. citri fase nimfa pada tanaman jeruk dengan konsentrasi 0,1 dan $1 \%$ dan untuk fase imago pada konsentrasi yang lebih besar yaitu $10 \%$.

\section{KESIMPULAN}

Hasil penelitian ini dapat disimpulkan bahwa:

1. Bioinsektisida ekstrak kulit jeruk JC pada konsentrasi $0,1 \%$ dan $1 \%$ efektif untuk mengendalikan kutu loncat $D$. citri fase nimfa, untuk fase imago efektif pada konsentrasi $10 \%$.

2. Berdasarkan nilai $\mathrm{LC}_{50}$ dan $\mathrm{LC}_{90}$ yang diperoleh bioinsektisida ekstrak kulit jeruk JC lebih efektif terhadap nimfa D. citri dibandingkan dengan imago.

3. Konsentrasi 0.1 dan $1 \%$ efektif untuk mengendalikan nimfa $D$. citri dan untuk pengendalian imago perlu konsentrasi yang lebih besar hingga $10 \%$.

\section{DAFTAR PUSTAKA}

\section{Balitjestro. 2015. Mengenal Penyakit CVPD (Huanglongbing). http://balitjestro.litbang.pertani an.go.id/penyakit-cvpd- huanglongbing-pada-tanaman- jeruk/. Diakses pada 12 Maret 2019.}

Badan Pusat Statistik dan Direktorat Jenderal Hortikultura. 2015. Luas Panen Jeruk Siam/Keprok Menurut Provinsi, 2011-2015. 
Bernays EA dan Chapman RF. 1994. Host Plant Selection by Phytophagous Insects. Chapman \& Hall Inc. New York.

Boina DR, Onagobla EO, Salyani M, Stelinski L. 2009. Influence of Posttreatment Temperature on the Toxicity of Insecticides Against Diaphorina citri (Hemiptera: Psyllidae). $J$. Econ. Entomol. 102(2): 685691

Bove' JM. 2006. Huanglongbing: A Destructive, Newly Emerging Century-Old Disease of Citrus. J.Plant Pathol.88(1): 7-37.

Dadang dan Prijono Dj. 2011. Pengembangan Teknologi Formulasi Insektisida Nabati Untuk Pengendalian Hama Sayuran Dalam Upaya Menghasilkan Produk Sayuran Sehat. Jurnal Ilmu Pertanian Indonesia. 16 (2): 100-111.

Dwiastuti ME. 2000. Evaluasi Ketahanan Varietas Jeruk Terhadap Penyakit CVPD Isolat Lumajang. J. Hort. 10(1):2129.

Dwiastuti ME, A Triwiratno, dan UN Taflikah. 2003. Hubungan Gejala Blotching, Defisiensi Zn dan Fe dengan Hasil Deteksi Penyakit CVPD Jeruk dengan Polymerase Chain Re ac tion. $J$. Hort. 13(2):131-137.

Dwiastuti ME, A Triwiratno, O Endarto, Wuryantini $S$ dan Yunimar. 2011. Pengenalan dan Pengendalian Hama dan Penyakit Tanaman Jeruk. Balai Penelitian Tanaman Jeruk dan Buah Subtropika. Badan Litbang Pertanian.

Harborne JB. 1993. Introduction to ecological biochemistry. 4th edn. Academic Press, London. P.318.
Harwanto, Wuryantini S, Endarto E, dan Yunimar. 2015. Teknologi Bioprosesing Insektisida Botani yang Bersumber dari Metabolit Sekunder yang Dihasilkan tanaman. Laporan Penelitian. Balai Penelitian Tanaman Jeruk dan Buah Subtropika.

Harwanto, Wuryantini S, Endarto E, dan Yunimar. 2016. Teknologi Proses Produk Metabolit Sekunder Tanaman sebagai Insektisida Botani terhadap Hama Utama Tanaman Jeruk. Laporan Penelitian. Balai Penelitian Tanaman Jeruk dan Buah Subtropika.

Katoh A, H Ohki, K Inai dan T.Hashimoto. 2005. Molecular Regulation of Nicotine Biosynthesis. Mini review. Plant Biotech. 22:389392.

Mead FW, Fasulo TR. 2011. Asian citrus psyllid, Diaphorina citri Kuwayama (Insecta: Hemiptera: Psyllidae). EENY. 33. IFAS Extention. Univ of Florida.

Swari NP, Adiartayasa MW, Wijaya IN. 2014. Deteksi Penyakit Citrus Vein Phloem Degeneration (CVPD) dengan Teknik Polymerase Chain Reaction (PCR) pada Tanaman Jeruk di Bali. E-Jurnal Agroekoteknologi Tropika. 3(2): 70.

Voight R. 1995. Buku Pelajaran Teknologi Ekstraksi. Diahlibahasakan oleh Soewandhi SN Edisi 5. Yogyakarta: Gadja Mada University Press.

Wijaya IN. 2003. Diaphorina citri KUW (Homoptera: Psyllidae): Bioteknologi dan Peranannya Sebagai Vektor Penyakit CVPD (Citrus Vein Phloem Degeneration) Pada Tanaman Jeruk Siam. [Disertasi] Bogor: 
Program Pascasarjana Institut

Pertanian Bogor

Wirawan IGP, Sulistyowati L. dan Wijaya

IN. 2003. Mekanisme Tingkat

Molekul Infeksi Penyakit

CVPD pada Tanaman Jeruk

dan Peran Diaphorina citri

Kuw. Sebagai Serangga

Vektor. Denpasar. Lemlit.

Universitas Udayana.

Wijaya IN, Adiartayasa W, Sritamin M, dan Yuliadhi KA. 2010. Dinamika

Populasi Diaphorina citri Kuwayama (Homoptera: Psyllidae) dan Deteksi CVPD dengan Teknik PCR. Jurnal Entomologi Indonesia. 7(2):7887.

Yusuf R. 2012. Potensi Dan Kendala Pemanfaatan Pestisida Nabati Dalam Pendalian Hama Pada Budidaya Sayuran Organik. Seminar UR-UKM ke-7 2012 "Optimalisasi Riset Sains dan Teknologi Dalam Pembangunan Berkelanjutan". 171-173. http//repository.unri.ac.id. 